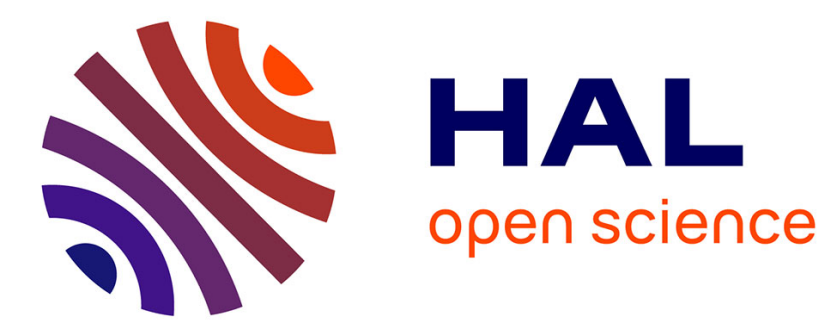

\title{
Effect of condensed tannins on methane emission and ruminal microbial populations
}

Moufida Rira, Carine Marie-Magdeleine, Harry Archimède, Diego Morgavi, Michel M. Doreau

\section{- To cite this version:}

Moufida Rira, Carine Marie-Magdeleine, Harry Archimède, Diego Morgavi, Michel M. Doreau. Effect of condensed tannins on methane emission and ruminal microbial populations. 4. International Symposium on Energy and Protein Metabolism and Nutrition (ISEP), Sep 2013, Sacramento, United States. 2 p., 10.3920/978-90-8686-781-3_186 . hal-02749298

\section{HAL Id: hal-02749298 \\ https://hal.inrae.fr/hal-02749298}

Submitted on 3 Jun 2020

HAL is a multi-disciplinary open access archive for the deposit and dissemination of scientific research documents, whether they are published or not. The documents may come from teaching and research institutions in France or abroad, or from public or private research centers.
L'archive ouverte pluridisciplinaire HAL, est destinée au dépôt et à la diffusion de documents scientifiques de niveau recherche, publiés ou non, émanant des établissements d'enseignement et de recherche français ou étrangers, des laboratoires publics ou privés. 


\title{
Effect of condensed tannins on methane emission and ruminal microbial populations
}

\author{
M. Rira ${ }^{1,2}$, C. Marie-Magdeleine ${ }^{2}, H$. Archimède $^{2}$, D.P. Morgavi ${ }^{I}$ and M. Doreau ${ }^{I}$ \\ ${ }^{1}$ INRA, UMR 1213 Herbivores, 63122 Saint-Genès-Champanelle and Clermont Université, VetAgro \\ Sup, UMR Herbivores, BP 10448,63000,Clermont-Ferrand, France; michel.doreau@clermont.inra.fr \\ 'Unité de Recherches Zootechniques, INRA, 97170 Prise d'Eau Petit-Bourg, Guadeloupe, France
}

\section{Introduction}

Enteric methane $\left(\mathrm{CH}_{4}\right)$ produced by domestic ruminants represents approximately $15 \%$ of the global emissions of this potent greenhouse gas. For reducing rumen $\mathrm{CH}_{4}$ emission various compounds have been tested as feed additives. Among these compounds, tannins are considered a promising group of natural additives. A meta-analysis by Jayanegara et al. (2012) showed that condensed and hydrolysable tannins might reduce $\mathrm{CH}_{4}$ production. However, it is still unclear (1) whether tannin supplementation reduces rumen $\mathrm{CH}_{4}$ in every situation and (2) to which extent this is associated with adverse effects on digestibility and their potential toxicity to some rumen micro-organisms (Goel et al., 2005). In this experiment we investigated the effect of tanniniferous tropical plants on enteric $\mathrm{CH}_{4}$ production and on numbers of methanogens, protozoa, and total and main cellulolytic bacteria.

\section{Material and methods}

Two sheep breeds were used, Texel $(T, n=4)$ of temperate origin and Blackbelly $(B, n=4)$ of tropical origin in two $4 \times 4$ Latin square designs. Diets, given ad libitum twice daily, consisted in tropical natural grassland based on Dichanthium spp. fed alone (C) or in association with 3 different tanniniferous forages given as pellets at $44 \%$ of the daily ration on average. The tanniniferous forages were leaves of Leucaena leucocephala (L), Glyricidia sepium (G) or Manihot esculenta (M). Total contents in condensed tannins measured by the vanillin- $\mathrm{H}_{2} \mathrm{SO}_{4}$ method were 75,39 and $92 \mathrm{~g} / \mathrm{kg}$ dry matter (DM) for $\mathrm{L}, \mathrm{G}$ and $\mathrm{M}$, respectively. Intake, total tract digestibility and $\mathrm{CH}_{4}$ production using the $\mathrm{SF}_{6}$ method were determined. For microbial parameters, rumen contents were sampled before the morning feeding. Microbial groups (total bacteria, Fibrobacter succinogenes, Ruminococcus albus, Ruminococcus flavefaciens and total methanogens) were enumerated by quantitative PCR (qPCR) using group-specific primers targeting the $r r s$ gene for bacteria and the $m c r A$ gene for methanogens. Protozoa were counted by microscopy. Statistical analyses were performed using the mixed procedure of SAS with period, diet, breed, and the diet $\mathrm{x}$ breed interaction as fixed effects and animal as random effect. Statistical differences were declared significant at $\mathrm{P} \leq 0.05$. Orthogonal contrasts between control diet and all tanniniferous forages were also determined.

\section{Results and discussion}

The addition of tannin-rich plants given as pellets increased DM intake probably due to the physical presentation (Table 1). Within tannin-rich plants, it was higher for $\mathrm{M}$ than for $\mathrm{G}$ diet. Intake per $\mathrm{kg}$ body weight was higher for Blackbelly than for Texel. Organic matter digestibility did not differ among diets and breeds, although contrast analysis showed a higher digestibility for $\mathrm{C}$ than for other diets. Daily $\mathrm{CH}_{4}$ production did not vary among diets and breeds, but $\mathrm{CH}_{4}$ production per $\mathrm{kg}$ DM intake was higher with $\mathrm{C}$ diet compared with tannin-rich diets. Within these latter diets, $\mathrm{CH}_{4}$ production was higher for $\mathrm{G}$ than for $\mathrm{M}$ and $\mathrm{L}$ diets. Concentration of total bacteria and $R$. flavefaciens was higher for $\mathrm{C}$ and $\mathrm{L}$ diets than for $\mathrm{G}$ and $\mathrm{M}$ diets; concentration of $R$. albus was lowest for $\mathrm{C}$ diet. The methanogens population was higher for Texel than for Blackbelly. In contrast the addition of condensed tannins did not influence the population of protozoa and $F$. succinogenes. 
Table 1. Intake, digestibility, methane emission and ruminal microbial populations in sheep fed tropical grassland hay $(C)$ alone or associated with tannins-containing plants Leucaena leucocephala $(L)$, Glyricidia sepium $(G)$ and Manihot esculenta $(M)$.

\begin{tabular}{|c|c|c|c|c|c|c|c|c|c|c|}
\hline \multirow{2}{*}{$\begin{array}{l}\text { Breed } \\
\text { Diet }\end{array}$} & \multicolumn{4}{|l|}{ Texel } & \multicolumn{4}{|c|}{ Blackbelly } & \multirow[t]{2}{*}{ SEM } & \multirow[t]{2}{*}{$P$ value $^{1}$} \\
\hline & $\mathrm{C}$ & $\mathrm{L}$ & $\mathrm{G}$ & $\mathrm{M}$ & $\mathrm{C}$ & $\mathrm{L}$ & $\mathrm{G}$ & M & & \\
\hline $\begin{array}{l}\text { DM intake, } \mathrm{g} / \mathrm{kg} \text { body } \\
\text { weight } / \mathrm{d}\end{array}$ & 16.28 & 24.45 & 20.72 & 27.68 & 16.62 & 25.96 & 24.49 & 31.54 & 1.877 & $\begin{array}{l}\text { B } 0.04 \\
\text { D }<0.01\end{array}$ \\
\hline $\begin{array}{l}\text { Organic matter } \\
\text { digestibility, \% }\end{array}$ & 69.66 & 64.94 & 62.69 & 62.36 & 70.12 & 65.74 & 62.78 & 66.97 & 3.639 & NS \\
\hline $\mathrm{CH} 4, \mathrm{~g} / \mathrm{kg} \mathrm{DM}$ intake & 32.06 & 24.23 & 28.83 & 24.28 & 29.98 & 15.89 & 24.98 & 15.26 & 2.147 & $\begin{array}{l}\text { B } 0.03 \\
\text { D }<0.01\end{array}$ \\
\hline Protozoa, $\log _{10}$ cells $/ \mathrm{ml}$ & 4.97 & 5.01 & 5.04 & 5.03 & 4.96 & 5.01 & 4.97 & 5.06 & 0.046 & NS \\
\hline Total bacteria ${ }^{2}$ & 11.91 & 11.90 & 11.80 & 11.84 & 11.89 & 11.96 & 11.85 & 11.81 & 0.041 & D 0.04 \\
\hline F. succinogenes ${ }^{2}$ & 9.71 & 9.79 & 9.61 & 9.72 & 9.67 & 9.85 & 9.64 & 9.68 & 0.079 & NS \\
\hline R. Albus ${ }^{2}$ & 8.00 & 8.79 & 8.33 & 8.49 & 7.60 & 8.42 & 8.34 & 8.16 & 0.261 & D 0.04 \\
\hline R. flavefaciens ${ }^{2}$ & 8.96 & 8.71 & 8.53 & 8.65 & 8.94 & 9.03 & 8.67 & 8.85 & 0.154 & D 0.05 \\
\hline Methanogens $^{3}$ & 10.00 & 9.85 & 9.72 & 9.84 & 9.76 & 9.71 & 9.70 & 9.74 & 0.082 & В 0.04 \\
\hline
\end{tabular}

${ }^{1} \mathrm{~B}=$ breed; $\mathrm{D}=$ diet. Breed $\times$ diet interaction was never significant.

${ }^{2}$ rrs copy number/g DM $\left(\log _{10}\right)$

${ }^{3}$ merA copy number $/ \mathrm{g}$ DM $\left(\log _{10}\right)$

Our results confirm that tannin-rich plants can limit $\mathrm{CH}_{4}$ production per $\mathrm{kg} \mathrm{DM}$ intake. The low effect of Glyricidia sepium on reduction of $\mathrm{CH}_{4}$ production could be explained by a low tannin concentration or by the intrinsic characteristics of Glyricidia sepium tannins. The presentation of tannin-rich plants as pellets probably decreased ruminal DM retention time which resulted in an increase in DM intake and can partially explain the reduction in $\mathrm{CH}_{4}$ production. As methanogens and protozoal numbers were not changed, further research is necessary to elucidate the relations between methane production and microbial activity in tannin-rich diets.

\section{Acknowledgements}

This research is a part of the AnimalChange project funded by the European Community's FP7 Programme. It was also funded by other EU funds (FEDER, FEADER) and by the Guadeloupe region. The first author received a fellowship from the Algerian Ministry of Higher Education and Research.

\section{References}

Goel, G., A.K. Puniya, C.N. Aguilar and K. Singh, 2005. Interaction of gut microflora with tannins in feeds. Naturwissenschaften 92, 497-503.

Jayanegara, A., F. Leiber, and M. Kreuzer, 2012. Meta-analysis of the relationship between dietary tannin level and methane formation in ruminants from in vivo and in vitro experiments. J. Anim. Physiol. Anim. Nutr. 96, 365-375. 


\section{Energy and protein metabolism and nutrition in sustainable animal production}

$4^{\text {th }}$ International Symposium on Energy and Protein Metabolism and Nutrition Sacramento, California, USA

9-12 September 2013

EAAP publication No. 134

\section{edited by:}

James W. Oltjen

Ermias Kebreab

Hélène Lapierre

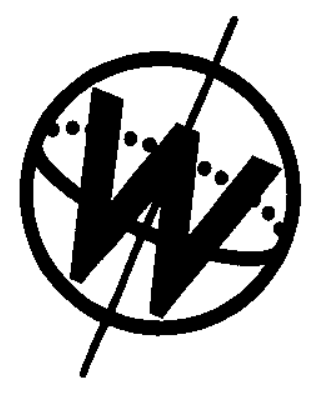

Wageningen Academic $P u b l i s h$ e $r s$ 